\title{
i2Metrix- Bộ công cụ đo lường năng lực đổi mới sáng tạo của doanh nghiệp
}

i2Metrix là bộ chỉ số đo lường năng lực đổi mới-sáng tạo-cạnh tranh của doanh nghiệp do Trung tâm Kinh doanh và Hỗ trợ Doanh nghiệp (BSA) và Công ty nghiên cứu kinh tế và tư vấn kinh doanh Dan Houtte, Vuong \& Partners Ltd (DHVP) cộng tác phát triển, cung cấp phương tiện định lượng để kiểm đếm quy mô nguồn lực sáng tạo, hiệu suất sử dụng và gợi ý giải pháp gia tăng hiệu quả khai thác nguồn lực này.Khác với những công cư đánh giá trước đây, i2Metrix ra đời từ thực tiễn và những hiểu biết về môi trường kinh doanh của cộng đồng doanh nghiệp Việt Nam, được tích lũy qua các chương trình hỗ trợ doanh nghiệp và hơn 10 năm nghiên cứu ứng dụng của các chuyên gia quốc tế.

i2Metrix xác định năng lực ĐMST của doanh nghiệp dựa trên một bộ câu hỏi chuẩn, gồm 60 câu hỏi được chia vào 10 nhóm chỉ tiêu bao gồm: lợi ích sinh ra từ ĐMST; nguồn nhân lực sáng tạo; nguồn lực tài chính đầu tư cho ĐMST; mức độ hỗ trợ mang tính chất tổ chức đối với định hướng ĐMST; mức độ tạo sự chuyên biệt hóa và khác biệt trong cạnh tranh thị trường; tính thích ứng với xu hướng nhu cầu, tầm nhìn về chu kỳ sống của sản phẩm, sức ảnh hưởng xu hướng; năng lực xử lý thông tin đa tầng tạo hiểu biết để chuẩn bị cho quá trình ĐMST; năng lực xây dựng lõi giá trị văn hóa thích ứng với thay đổi và định hướng ĐMST; khả năng điều phối nhịp nhàng để một ý tưởng được quyết tâm đầu tư đến đích sản phâm, đưa ra thị trường và cải tiến cho tới bán hàng; năng lực quan sát, dự báo nguy cơ và đánh giá khả năng đáp ứng nguy cơ từ bên trong doanh nghiệp.

Các kích thước và chỉ tiêu đo lường cung cấp phương tiện để doanh nghiệp hình dung trực quan về hiện trạng năng lực đổi mới-sáng tạo của chính mình. Từ đó, định hướng và giải pháp cải thiện, tăng cường sức cạnh tranh được xây dựng với sự phân bổ nguồn lực hợp lý hơn. Từng chỉ tiêu định lượng sẽ là những tiêu chí rõ ràng để doanh nghiệp đối chiếu và xác định vị thế với đối thủ cạnh tranh, trong ngành và trên toàn thị trường.Với những người làm chính sách và nghiên cứu, bộ dữ liệu i2Metrix cung cấp bằng chứng thực nghiệm và chỉ rõ những nội dung cần ưu tiên trọng điểm về nguồn lực, chính sách và giải pháp trong thúc đẩy, hỗ trợ đổi mới-sáng tạo. Trên thị trường, các nhà đầu tư có tín hiệu để nhận biết tiềm năng phát triển trong tương lai của doanh nghiệp. Công chúng tiêu dùng có thêm thông số tin cậy để lựa chọn hàng hóa và dịch vụ cũng như tăng cường hiểu biết một cách trực quan và sinh động về lao động đổi mới-sáng tạo vốn mang tính trừu tượng 
Tại các tỉnh phía Nam, Việt Nam, đã tiến hành triển khai cho 25 doanh nghiệp trên nhiều các lĩnh vực khác nhau và nhận được nhiều nhận xét, đánh giá cao từ các nhà nghiên cứu, lãnh đạo địa phương và doanh nghiệp. Sau đây là một số ý kiến đánh giá của các chuyên gia và các doanh nghiệp:

Theo PGS. TS. Vũ Văn Khiêm, Cục trưởng Cục công tác phía Nam Bộ KH\&CN: "doanh nghiệp nên đo i2Metrix mới biết mình đang ở đâu để có cơ sở để đánh giá và kiểm đếm về mình, nếu làm tốt và tiếp tục hoàn thiện thì bộ công cụ i2Metrix trong tương lai sẽ được Bộ KH\&CN xem như một "cẩm nang" để đo năng lực đổi mới sáng tạo của doanh nghiệp"

Giáo sư Nancy K. Napier Giám đốc Trung tâm Đổi mới và Sáng tạo, Trường Kinh tế và Kinh doanh, Đại học Boise State (Idaho, Hoa Kỳ), Cổ vấn học thuật của i2Metrix cho rằng: "“i2Metrix sẽ rất hữu ích không chỉ riêng cho Việt Nam. Đây là một phương thức đo lường năng lực đổi mới và sáng tạo có cách tiếp cận khách quan để đánh giá "lợi ích" từ nỗ lực thực thi công việc một cách khác biệt. i2Metrix cũng giúp xác định đầu tư vào đâu để đổi mới-sáng tạo mang lại giá trị tốt nhất."

Giáo su Dolly Samson Phó Chủ tịch Stamford International University (Bangkok, Thái Lan), Cố vấn học thuật của i2Metrix: "Cộng đồng Kinh tế ASEAN ra đời vào 2015 mang đến thị trường cạnh tranh mới, thúc đẩy các tổ chức nỗ lực gia tăng năng lực đồi mới. 10 kích thước của i2Metrix cung cấp những chî̉ dẫn cụ thể và định lượng cho các nhà quản trị đang tìm kiếm cơ hội tiến vào thị trường mới và tạo sự khác biệt cho sản phẩm và dịch vụ của doanh nghiệp mình thông qua các dự án đổi mới và sáng tạo. Thái Lan đang nỗ lực xây dựng mô hình tăng trưởng kinh tế với động lực sáng tạo. Theo đó, những gợi ý của i2Metrix sẽ được đặc biệt chào đón.”

Ông Nguyễn Bá Lâm, Giám đốc R\&D, Công ty cổ phần Sản xuất nhựa Duy Tân: "Lãnh đạo Duy Tân thường nghĩ, mình cứ lặng lẽ làm chứ không thích quảng bá ồn ào. Bảng câu hỏi i2Metrix thì dài, khá phức tạp nên chúng tôi rất đắn đo. Nhưng cuối cùng chúng tôi chấp nhận tham gia vì muốn biết được ý kiến nhận xét nhiều chiều về hoạt động Đổi mới sáng tạo của công ty mình. Vì tuy mình cố gắng hết sức nhưng vẫn còn nhiều điều chưa hài lòng, vậy thì còn khiểm khuyết chỗ nào, điểm nào cần bổ sung, tập trung hơn? Muốn được nghe thì phải chia sẻ, rất mong các ý kiển khác góp cho Duy Tân tiến bộ"

Ông Văn Đức Mười, Tổng Giám đốc Vissan: "Theo tôi, việc nhìn nhận bộ tiêu chí này cũng tùy theo góc độ của từng $\mathrm{DN}$. Nếu $\mathrm{DN}$ có chuẩn bị sã̃n sàng và có tổ chức tốt cho đổi mới sáng tạo, nó là một thông lệ bình thường để phát triển.

Song trong thực tế, nhiều DNVN chưa có chương trình đổi mới sáng tạo cho riêng mình sẽ cảm thấy hơi quá sức với bộ chỉ số này. Nhưng khi quá sức chúng ta mới có tầm với, mới có thể tăng "chiều cao" của mình còn nếu chỉ ngang tầm sẽ khó có động lực cho sự phát 
triển"

ông Kao Siêu Lực Tổng Giám đốc ABC Backery: "Tôi luôn tâm niệm rằng muốn cạnh tranh, mình phải vươn lên đi đầu, chứ đừng chạy theo người ta về công nghệ, thiết bị. Những máy móc sản xuất bánh kẹo của chính xưởng cơ khí - điện của chúng tôi làm ra hiện nay đã xuất sang nhiều nước trên thế giới. Tuy nhiên, chúng tôi cũng không đo được hết các chỉ số về năng lực ĐMST, vì thế việc đo lường bằng bộ chỉ số i2Metrix giúp chúng tôi tự hệ thống và đánh giá về chính hoạt động ĐMST của mình và thực sự nó rất cần kíp cho DN". 
